\title{
Особенности формирования земельного рынка в губерниях Центрально-Промышленного и Центрально-Черноземного районов в 1860-1890-е годы
}

\author{
Громова В.В. \\ Белгородский государственный национальный исследовательский университет, \\ Россия, 308015, г. Белгород, ул. Победы, 85 \\ E-mail: Gromvv@mail.ru
}

\begin{abstract}
Аннотация. После крестьянской реформы 1861 года появились предпосылки для развития земельного рынка, поскольку постепенно стали сниматься сословные ограничения для свободного перехода земли в собственность других сословий. В статье рассматривается особенности земельных рынков в губерниях Центрально-Черноземного и Центрально-Промышленного районов в 60-90-е годы XIX века. На основе данных материалов по статистике движения землевладения в России проведен анализ формирования земельного рынка по каждой губернии указанных районов за период с 1863 по 1892 годы. В основу анализа были положены цены на землю. По пятилетиям рассмотрена динамика земельных цен в целом Европейской России и в частности в двух центральных районах. В зависимости от уровня земельных цен, губернии каждого из районов были разделены на две группы - губернии с высокими и низкими ценами на землю. В каждой группе губерний были рассмотрены основные показатели земельного рынка: количество сделок по купле-продаже земли, ее стоимость, количество проданных десятин. Путем вычисления были рассчитаны средние цены на землю и среднее количество земли, приходящиеся на одну сделку. Эти данные позволили определить степень влияния земельных цен на особенности развития внутригубернских земельных рынков в двух центральных районах.
\end{abstract}

Ключевые слова: земельный рынок, цена, рубли, десятина, сделка, губерния, пятилетие, динамика, показатели, территория.

Для цитирования: Громова В.В. 2021. Особенности формирования земельного рынка в губерниях Центрально-Промышленного и Центрально-Черноземного районов в 1860-1890-е годы. Via in tempore. История. Политология, 48 (2): 405-414. DOI: 10.52575/2687-0967-2021-48-2-405-414.

\section{Formation features of the land market in the Central Industrial Region and the Central Chernozem Region from the 1860's to the 1890's}

\author{
Victoriya V. Gromova \\ Belgorod National Research University, \\ 85 Pobeda St., Belgorod, 308015, Russia \\ E-mail: Gromvv@mail.ru
}

\begin{abstract}
After the Emancipation Reform of 1861 preconditions of the land market development had come about as restrictions on inter-caste land redistribution had been removed by and by. The article is dedicated to the features of the land market in the Central Chernozem Region and the Central Industrial Region from the 1860's to the 1890's. Due to the land trading statistics an analysis of the formation of the land market of each province of mentioned regions was undertaken. The analysis captures the period between 1863 and 1892. It is based on land prices. Land prices trends in five year periods were considered in the whole European Russia and in two Central provinces privately. Depending on the level of land prices, provinces of each region were divided into two groups -1 ) provinces with high land prices, and 2) provinces with low ones. Main indicators of each group were identified: such as amount of


transactions in land, land prices, amount of sold dessiatinas. Average land prices and amount of land allocated to one deal were distinguished by calculating. This data revealed the impact of the land prices on development features of provincial land markets in two Central regions.

Key words: land market, price, ruble, dessiatina, transaction, province, five year period, trends, indicators, territory.

For citation: Gromova V.V. 2021. Formation features of the land market in the Central Industrial Region and the Central Chernozem Region from the 1860's to the 1890's. Via in tempore. History and political science, 48 (2): 405-414 (in Russian). DOI: 10.52575/2687-0967-2021-48-2-405-414.

\section{Введение}

Земельный рынок является одним из ключевых компонентов единого аграрного рынка, степень развития которого характеризует развитие капитализма в России во второй половине XIX века. Важнейшей стороной в развитии любого товарного рынка является динамика цен [Ковальченко, Милов, 1974]. Посредством анализа земельных цен в Центрально-Промышленном и Центрально-Черноземном районах можно проследить развитие земельного рынка в 60-х - 90-х годах XIX века и выявить его особенности в зависимости от локализации.

Центрально-Промышленный район включает 8 губерний: Московскую, Владимирскою, Калужскую, Тверскую, Костромскую, Ярославскую, Нижегородскую, Смоленскую. Центрально-Черноземный район - 10 губерний: Воронежскую, Курскую, Орловскую, Рязанскую, Тамбовскую, Тульскую, Казанскую, Пензенскую, Саратовскую и Симбирскую.

Территория восьми губерний Центрально-Промышленного района составляла 37 млн дес. На десять губерний Центрально-Черноземного района приходилось 48,9 млн дес. [Островский, 2013, с. 25].

К сожалению, в распоряжении исследователей не имеется обобщенных данных о стоимости земли по угодьям за период с 1863 по 1892 годов. Вместе с тем стоимость земли, реализуемой в один и тот же год, в одной и той же губернии может существенно различаться в зависимости от ее категории (пашня, луг, сенокос, лес и пр.).

Например, в Воронежских губернских ведомостях за 1863 год можно увидеть следующие объявления о совершении купчих крепостей в Воронежской губернии и одноименном уезде губернии: жена купца Кудинова А.И. продала жене губернского секретаря Епсихеевой А.И. 4 десятины 10 сажень незаселенной земли с лесом за 400 рублей серебром. Почетные граждане Аврамовы Алексей и Николай продали купцу Ляпину Н.И. лесную рощу с земляными угодьями в размере 497 десятин за 10 тыс. руб. серебром. Дворянка Воронкова Р.В. продала жене купца Сафоновой М.Т. 7 дес. распашной земли за 300 руб. серебром [Воронежские губернские ведомости, 1863, с. 278-358]. В первом случае десятина земли стоила около 100 руб., во втором - 20 руб., в третьем - 43 рубля.

\section{Объекты и методы исследования}

Объектом исследования настоящий статьи является земельный рынок Европейской России во второй половине XIX века на примере губерний Центрально-Промышленного и Центрально-Черноземного районов.

С помощью историко-статистического метода были обработаны имеющиеся в материалах обширные данные по статистике землевладения в России и определен ряд показателей земельного рынка:

1) количество сделок по купле-продаже, стоимость земли, количество десятин. Данные показатели рассчитаны путем сложения за тридцатилетний период с 1863 по 1892 гг.;

2) средние цены на землю и среднее количество земли, приходящиеся на одну сделку. Данные показатели были рассчитаны путем среднеарифметического вычисления 
за тридцатилетний период с 1863 по 1892 гг. и, в частности, за два пятилетних периода с 1863 по 1867 гг. и с 1887 по 1892 гг.

Анализ вышеприведенных показателей позволил выявить и исследовать динамику развития земельных рынков в двух центральных районах.

\section{Результаты и их обсуждение}

Динамика цен показывает следующие особенности развития земельного рынка Европейской России во второй половине XIX века.

В среднем в 45 губерниях Европейской России с 1863 по 1892 годы по пятилетиям цена за десятину земли составляла: с 1863 по 1867 гг. - 14,73 руб., с 1868 по 1872 гг. 20,44 руб., или на 39 \% больше, чем в предыдущем пятилетие [Материалы по статистике..., 1907].

С 1873 по 1877 гг. цены на землю снизились на 4 \% - до 19,44 руб. за десятину. Это связано со снижением цен на землю в отдельных губерниях нечерноземной полосы. Например, в Калужской губернии за указанные пятилетия цена на землю снизилась на $21 \%$ (с 24,35 до 19,13 руб. за дес.), в Нижегородской губернии - на $13 \%$ (с 27,02 до 23,54 за десятину земли) [Материалы по статистике..., 1907]. Трудно сказать, чем это было вызвано. Возможно, изменился состав угодий [Ковальченко, Милов, 1974, с. 257].

В черноземных губерниях в это время цены на землю продолжали расти. С 1873 года цены стали расти повсеместно. С 1873 по 1877 гг. цена земли увеличилась на $15 \%$ - до 22,29 руб., а с 1883 по 1887 гг. - на $40 \%$ (до 31,11 руб.), с 1888 по 1892 гг. - на 29 \% (до 40,27 руб. за дес.) [Материалы по статистике..., 1907].

Губернии Центрально-Черноземного района отличались от других губерний Европейской России высокими ценами на землю. С 1863 по 1882 гг. в ЦентральноЧерноземном районе земля была самой дорогой по стоимости в Европейской России. С 1863 по 1872 гг. десятина земли в районе в среднем стоила 31,28 руб., с 1873 по 1882 гг. - в 1,4 раза больше - 45,22 рубля за десятину. С 1883 по 1892 гг. цены на землю в районе выросли еще в 1,4 раза - до 64,27 руб. за дес. Этот район стал на втором месте по уровню земельных цен после Малороссийских губерний (Полтавской, Харьковской, Черниговской), где земля в этот период времени продавалась по 70,62 рубля за десятину [Материалы по статистике..., 1907].

По среднему уровню цен на землю, рассчитанному за тридцатилетний период с 1863 по 1892 гг., губернии района условно можно разделить на две группы. Первая группа - губернии с высокими ценами на землю - от 46 до 67 рублей за десятину. В эту группу входили губернии Черноземного Центра: Курская, Тульская, Воронежская, Тамбовская, Орловская и Рязанская. Вторая группа - губернии с более низкой стоимостью земли - от 33 до 42 руб. за десятину. В нее вошли восточные губернии района: Саратовская, Пензенская, Симбирская, Казанская [Материалы по статистике..., 1907].

Указанные группы губерний различались не только стоимостью земли, но и количеством сделок, а также средними размерами проданных и купленных участков.

Рассмотрим группу губерний с высокими ценами на землю. Эти губернии существенно различались средними размерами участков на земельном рынке. В каждой губернии этой группы имелись свои особенности земельного рынка. Из всех губерний выделялись Курская и Воронежская губернии.

В Курской губернии было совершено 42570 сделок по купле-продаже земли в два раза больше, чем в большинстве других губерний данной группы, а средние размеры проданных землевладений были значительно меньше. На одну сделку купли-продажи приходилось 24 десятины. Эта губерния отличалась самыми высокими ценами на землю в Центрально-Черноземном районе. Средняя стоимость десятины земли за тридцатилетний период с 1863 по 1892 гг. составила 67 рублей (см. табл. 1). 
К 1861 году в Курской губернии из 5323 дворянских имений 4652 имений (87\%) были мелкопоместными - от 1 до 100 душ. После реформы 1861 года мелкие и часть средних помещиков оказались неспособны выгодно вести собственное хозяйство и распродали свои земли крупным владельцам - купцам, частью - крестьянам [Дружинин, 1978, с. 230]. К 1884 году в губернии имелись крупные купеческие землевладения свыше 1000 дес. Например: в Дмитриевском уезде губернии купцу Храмченко П.С. принадлежало 1009 дес. ${ }^{9}$, купцу Минаеву М.П. - 1904 дес. ${ }^{10}$ В Фатежском уезде купцам Сыромятниковым принадлежало 1873 дес. ${ }^{11}$ C 1863 по 1884 гг. в губернии были примеры сокращения крупных дворянских землевладений. Так, до проведения реформы по отмене крепостного права в Рыльском уезде князю В.И. Барятинскому (вместе с крестьянскими землями) принадлежало 30373 десятин [Материалы редакционных комиссий..., 1860, с. 42-43]. В Новооскольском уезде землевладения князей Трубецких составляли 21079 десятин [Материалы редакционных комиссий..., с. 30-31]. К 1884 году в соответствующих уездах во владении фамилии князей Барятинских осталось 16179 дес. $^{12}$, князей Трубецких 5340 дес. $^{13}$

Таблица 1

Table 1

Основные показатели земельного рынка губерний Центрально-Черноземного района с 1863 по 1892 годы [Материалы по статистике..., 1907. Табл. I-IV]

The main indicators of the land market in the Central Chernozem region from 1863 to 1892

\begin{tabular}{|c|c|c|c|c|c|c|c|c|c|}
\hline \multirow{2}{*}{ Губернии } & \multirow{2}{*}{$\begin{array}{c}\text { Сдел- } \\
\text { ки }\end{array}$} & \multirow{2}{*}{$\begin{array}{c}\text { Кол-во } \\
\text { тыс. } \\
\text { дес. }\end{array}$} & \multirow{2}{*}{$\begin{array}{c}\text { Стои- } \\
\text { мость } \\
\text { земли } \\
\text { (тыс. } \\
\text { руб.) }\end{array}$} & \multicolumn{3}{|c|}{$\begin{array}{c}\text { Среднее } \\
\text { кол-во земли на } 1 \text { сделку } \\
\text { (дес.) } \\
\end{array}$} & \multicolumn{3}{|c|}{$\begin{array}{c}\text { Средняя цена } 1 \text { дес. } \\
\text { (руб.) }\end{array}$} \\
\hline & & & & $\begin{array}{c}1863- \\
1867\end{array}$ & $\begin{array}{c}1887- \\
1892\end{array}$ & $\begin{array}{c}1863- \\
1892\end{array}$ & $\begin{array}{l}1863- \\
1867\end{array}$ & $\begin{array}{c}1887 \\
- \\
1892\end{array}$ & $\begin{array}{c}1863 \\
-1892\end{array}$ \\
\hline Курская & 42570 & 1001 & 66811 & 40 & 22 & 24 & 30 & 103 & 67 \\
\hline Рязанская & 19479 & 1481 & 67540 & 68 & 62 & 76 & 29 & 72 & 46 \\
\hline Орловская & 16989 & 1026 & 50298 & 59 & 34 & 60 & 31 & 82 & 49 \\
\hline Тульская & 12438 & 1106 & 66155 & 97 & 76 & 89 & 32 & 91 & 60 \\
\hline Тамбовская & 11435 & 1502 & 83335 & 144 & 123 & 131 & 28 & 73 & 55 \\
\hline $\begin{array}{l}\text { Воронеж- } \\
\text { ская }\end{array}$ & 8143 & 1074 & 59162 & 99 & 73 & 132 & 35 & 83 & 55 \\
\hline
\end{tabular}

В Воронежской губернии было совершено наименьшее количество сделок по куплепродаже земли из всех губерний данной группы - 8143 сделок, а средние размеры проданных участков были самыми большими. На одну сделку приходилось 132 дес. Средняя стоимость десятины земли составляла 55 руб. - на $18 \%$ меньше, чем в Курской губернии.

В Тамбовской губернии было совершено 11435 сделок по купле продаже земли, немного больше, чем в Воронежской губернии. При этом средние размеры участков и стоимость земли на рынке были практически одинаковыми.

Тульская губерния по стоимости земли была на втором месте после Курской губернии. Средняя стоимость десятины земли в этой губернии составляла 60 рублей - на $10 \%$ ниже, чем в Курской губернии. Число сделок купли-продажи и количество земли, приходящиеся на одну сделку, соответствовало средним значениям данной группы. В этой

\footnotetext{
${ }^{9}$ Государственный архив Курской области (далее ГАКО). Ф. 4. Оп. 1. Д. 85. Л. 24.

${ }^{10}$ Там же. Л. 19.

${ }^{11}$ Там же. Д. 96. Л. 7. об.

${ }^{12}$ ГАКО. Ф. 4. ОП. 1. Д. 92. Л. 2-16.

${ }^{13}$ Там же. Д. 89. Л. 13.
} 
губернии было совершено 12438 сделок по купле-продаже земли. На одну сделку куплипродажи приходилось 89 дес. земли.

В Рязанской и Орловской губерниях цены были ниже, чем в остальных губерниях данной группы - 46 и 49 рублей за десятину соответственно. В Рязанской губернии было совершено 19479 сделок по купле-продаже земли, в Орловской - 16989 сделок. На одну сделку приходилось 76 и 60 дес. земли соответственно.

Сравнение первого и последнего пятилетий рассматриваемого тридцатилетнего периода показывает следующее.

Среднее количество земли, приходящееся на одну сделку, уменьшилось во всех губерниях данной группы. В Курской и Орловской губерниях это уменьшение составляло более $40 \%$ (до 22 и 34 дес.), в Тульской и Воронежской - 20-26\% (до 76 дес. и 73 дес.), в Тамбовской - $15 \%$ (до 123 дес.) и в Рязанской - $9 \%$ (до 72 дес.).

Стоимость земли увеличилась во всех губерниях группы. Самый большой рост цен был в Курской губернии, где стоимость земли выросла в 3,4 раза - с 30 руб. за дес. до 103 руб. за дес. В остальных губерниях района цены выросли в 2,4-2,8 раза.

Рассмотрим особенности земельного рынка группы губерний с низкими ценами на землю с 1863 по 1892 годы.

В Саратовской, Пензенской и Симбирской губерниях было совершено практически одинаковое количество сделок по купле-продаже земли - по 6,8 тыс. в каждой. В Казанской губернии было совершено в два раза меньше сделок, чем в первых трех - 3,1 тыс. сделок (см. табл. 2).

Таблица 2

Table 2

Основные показатели земельного рынка губерний Центрально-Черноземного района с 1863 по 1892 годы [Материалы по статистике..., 1907. Табл. I-IV]

The main indicators of the land market in the Central Chernozem region from 1863 to 1892

\begin{tabular}{|c|c|c|c|c|c|c|c|c|c|}
\hline \multirow{2}{*}{ Губернии } & \multirow{2}{*}{ Сделки } & \multirow{2}{*}{$\begin{array}{c}\text { Кол-во } \\
\text { тыс. дес. }\end{array}$} & \multirow{2}{*}{$\begin{array}{c}\text { Стоимость } \\
\text { земли } \\
\text { (тыс. руб.) }\end{array}$} & \multicolumn{3}{|c|}{$\begin{array}{c}\text { Среднее кол-во земли } \\
\text { на } 1 \text { сделку (дес.) }\end{array}$} & \multicolumn{3}{|c|}{$\begin{array}{c}\text { Средняя цена } 1 \text { дес. } \\
\text { (руб.) }\end{array}$} \\
\hline & & & & $\begin{array}{c}1863- \\
1867\end{array}$ & $\begin{array}{c}1887- \\
1892\end{array}$ & $\begin{array}{c}1863- \\
1892\end{array}$ & $\begin{array}{c}1863- \\
1867\end{array}$ & $\begin{array}{c}1887- \\
1892\end{array}$ & $\begin{array}{c}1863- \\
1892\end{array}$ \\
\hline Саратовская & 6895 & 1969 & 70116 & 252 & 249 & 286 & 23 & 48 & 36 \\
\hline Пензенская & 6847 & 1058 & 44758 & 120 & 129 & 155 & 22 & 56 & 42 \\
\hline Симбирская & 6812 & 1122 & 38198 & 259 & 113 & 165 & 23 & 50 & 34 \\
\hline Казанская & 3194 & 576 & 19103 & 285 & 159 & 180 & 19 & 44 & 33 \\
\hline
\end{tabular}

В Саратовской губернии земля продавалась самыми крупными участками в районе. На одну сделку приходилось 286 дес. земли. В Пензенской губернии были самые высокие цены на землю (56 руб.), а среднее количество земли, приходящееся на одну сделку, было меньше (155 дес.), чем в других губерниях группы.

Для того чтобы увидеть изменение цен и средних размеров продаваемых участков за тридцатилетний период с 1863 по 1892 гг., сравним средние значения за первое (с 1863 по 1867 гг.) и последнее (с 1887 по 1892 гг.) пятилетия.

В 1887-1892 годах по сравнению с 1863-1867 годами в Симбирской и Казанской губерниях среднее количество земли, приходящейся на одну сделку, уменьшилось в два раза. В Пензенской губернии - увеличилось на $7 \%$, а в Саратовской практически не изменилось. Стоимость земли за указанные пятилетия во всех четырех губерниях выросла в 2-2,5 раза.

В Центрально-Промышленном районе на протяжении рассматриваемого тридцатилетнего периода с 1863 по 1892 годы стоимость земли была практически в 1,3-2 раза выше, чем в других районах нечерноземной полосы, но в 1,8-2,5 раза ниже, чем в Центрально-Черноземном районе. Например, с 1863 по 1872 годы средняя стоимость десятины зем- 
ли в Центрально-Промышленном районе составляла 17,07 рублей, в Северном - 6,93 руб., в Западном - 11,68 рублей. В Центрально-Черноземном районе в этот период времени земля стоила 31,29 рублей за дес. С 1882 по 1892 годы средняя стоимость десятины земли была следующей: в Центрально-Промышленном районе - 26,46 руб., в Северном и Западном - 13,42 руб. и 19,47 руб., а в Центрально-Черноземном районе - 64,27 рублей [Материалы по статистике..., 1907].

Рассмотрим особенности земельных рынков губерний ЦентральноПромышленного района, основываясь на приведенных выше показателях.

В отличие от губерний Центрально-Черноземного района, губернии ЦентральноПромышленного района более существенно различались между собой по стоимости земли. Взаимосвязи между стоимостью земли, количеством сделок по купле-продаже и средними размерами продаваемых участков в губерниях Центрально-Промышленного района не прослеживается.

Губернии Центрально-Промышленного района, как и губернии ЦентральноЧерноземного района, по стоимости земли можно разделить на две группы. Губернии с низкими ценами на землю - Костромская, Смоленская, Ярославская и Тверская. Губернии с высокими ценами на землю - Владимирская, Нижегородская, Калужская и Московская (см. табл. 3).

Таблица 3

Table 3

Основные показатели земельного рынка губерний Центрально-Промышленного района с 1863 по 1892 годы [Материалы по статистике..., 1907. Табл. I-IV].

The main indicators of the land market in the Central Industrial region from 1863 to 1892

\begin{tabular}{|c|c|c|c|c|c|c|c|c|c|}
\hline \multirow{2}{*}{ Губернии } & \multirow{2}{*}{$\begin{array}{c}\text { Сдел- } \\
\text { ки }\end{array}$} & \multirow{2}{*}{$\begin{array}{l}\text { Кол- } \\
\text { во } \\
\text { тыс. } \\
\text { дес. }\end{array}$} & \multirow{2}{*}{$\begin{array}{c}\text { Стои- } \\
\text { мость } \\
\text { земли } \\
\text { (тыс. руб.) }\end{array}$} & \multicolumn{3}{|c|}{$\begin{array}{c}\text { Среднее кол-во земли } \\
\text { на } 1 \text { сделку (дес.) }\end{array}$} & \multicolumn{3}{|c|}{ Средняя цена 1 дес. (руб.) } \\
\hline & & & & $\begin{array}{c}1863- \\
1867\end{array}$ & $\begin{array}{c}1887- \\
1892\end{array}$ & $\begin{array}{c}1863- \\
1892\end{array}$ & $\begin{array}{c}1863- \\
1867\end{array}$ & $\begin{array}{c}1887- \\
1892\end{array}$ & $\begin{array}{c}1863- \\
1892\end{array}$ \\
\hline Тверская & 25040 & 2166 & 38040 & 83 & 64 & 87 & 14 & 26 & 18 \\
\hline Ярославская & 18583 & 1064 & 18871 & 63 & 51 & 57 & 18 & 23 & 18 \\
\hline Смоленская & 16594 & 3233 & 47292 & 131 & 168 & 195 & 10 & 22 & 15 \\
\hline Костромская & 15385 & 2721 & 24346 & 183 & 139 & 177 & 8 & 10 & 9 \\
\hline $\begin{array}{l}\text { Владимир- } \\
\text { ская }\end{array}$ & 14073 & 1614 & 40002 & 153 & 74 & 115 & 17 & 41 & 25 \\
\hline Московская & 10083 & 1207 & 69825 & 133 & 96 & 120 & 37 & 88 & 58 \\
\hline Калужская & 9630 & 1119 & 30473 & 103 & 98 & 116 & 23 & 38 & 27 \\
\hline Нижегородская & 8150 & 1098 & 28599 & 139 & 174 & 135 & 20 & 25 & 26 \\
\hline
\end{tabular}

Особенности губерний с низкими ценами на землю заключались в следующем.

В Тверской и Ярославской губерниях было совершено самое большое количество сделок по купле-продаже земли в районе - 25 тыс. и 18,5 тыс. сделок. Десятина земли в этих губерниях в среднем стоила 18 рублей. Среднее количество земли, приходящейся на одну сделку, составляло 87 дес. и 57 дес. соответственно.

В Смоленской и Костромской губерниях земля продавалась самыми крупными участками в районе. На одну сделку купли-продажи приходилось 195 дес. и 177 дес. В этих губерниях было совершено соответственно 16,5 тыс. и 15,3 тыс. сделок куплипродажи земли, что было немного выше среднего по району (14,6 тыс. сделок). В Смоленской губернии средняя стоимость земли составляла 15 руб. за дес. В Костромской губернии земля стоила дешевле почти в два раза - 9 руб. за десятину.

Губернии района с высокими ценами на землю были более однородны по рассматриваемым показателям. 
Во Владимирской и Нижегородской губерниях средняя стоимость земли составляла 26 рублей за десятину. В Калужской - 27 рублей. В Нижегородской и Калужской губерниях было совершено минимальное количество сделок по купле-продаже земли в районе - 8,1 тыс. и 9,6 тыс. сделок. Во Владимирской количество сделок почти в два раза больше - 14 тыс. сделок. Среднее количество земли, приходящееся на одну сделку, в этих губерниях было следующим: в Нижегородской - 135 дес., В Калужской - 116 дес., во Владимирской - 115 дес.

Московская губерния отличалась от остальных губерний района самыми высокими ценами на землю. Средняя стоимость десятины земли в губернии составляла 58 рублей. Количество сделок по купле-продаже земли было немного ниже среднего - 10 тыс. сделок. На одну сделку приходилось 120 дес.

Сравнение средних значений за первое (с 1863 по 1867 гг.) и последнее (с 1887 по 1892 гг.) пятилетия рассматриваемого тридцатилетнего периода (с 1863 по 1892 гг.) показывает следующие изменения.

В Нижегородской и Смоленской губерниях среднее количество земли, приходящееся на одну сделку купли-продажи, увеличилось на $25 \%$ и 28 \% (до 174 дес. и 168 дес. соответственно). Во всех остальных губерниях района - уменьшилось. В Тверской, Ярославской, Костромской и Московской губерниях - на 19-28 \%. Во Владимирской - на $5 \%$.

Во всех губерниях района цены на землю выросли, но этот рост был не одинаковым. Самый большой рост цен на землю наблюдался в Московской и Владимирской губерниях. В этих губерниях цены выросли в 2,4 раза. В Тверской и Смоленской - в 1,9-2,2 раза. В Калужской - в 1,6 раза. В Ярославской и Нижегородской в 1,3 раза. Самый маленький рост цен был в Костромской губернии - стоимость земли увеличилась в 1,2 раза.

\section{Заключение}

Приведенные данные по губерниям Центрально-Черноземного района показывают следующее.

Из всех губерний с высокими ценами на землю особенно выделялась Курская губерния. В ней совершалось в 2-3 раза больше сделок, чем в остальных губерниях. Земля в ней стоила дороже, а средний размер участка земли на земельном рынке был значительно меньше. Воронежская и Тамбовская губернии отличались от остальных губерний тем, что в них было совершено наименьшее количество сделок по купле-продаже земли, но земля продавалась самыми крупными участками. При этом стоимость земли была средней в данной группе. Тульская губерния была на втором месте по стоимости земли после Курской губернии. В Рязанской и Орловской губерниях земля стоила дешевле, чем в остальных губерниях рассматриваемой группы. В губерниях района с низкими ценами на землю, в отличие от губерний с высокими ценами, совершалось меньше сделок купли-продажи земли, а среднее количество земли, приходящееся на одну сделку, было выше.

В губерниях Центрально-Промышленного района имелись свои особенности.

Больше всего сделок по купле-продаже земли было совершено в Тверской и Ярославской губерниях. В этих губерниях земля продавалась самыми мелкими участками в районе. В Смоленской и Костромской земля продавалась самыми крупными участками. Костромская губерния отличалась самой низкой стоимостью земли в районе.

В Нижегородской и Калужской губерниях было совершено наименьшее количество сделок в районе. В этих губерниях, а также во Владимирской губернии земля стоила практически одинаково. Во Владимирской губернии было совершено больше сделок, чем в первых двух губерниях.

Московская губерния отличалась самыми высокими ценами на землю в районе. Все остальные рассматриваемые показатели в этой губернии были средними по району. 
Таким образом, губернии Центрально-Промышленного района по среднему количеству земли, приходящейся на одну сделку, ценам на землю и их изменениям существенно различались.

В течение рассматриваемого тридцатилетнего периода с 1863 по 1892 гг. в губерниях Центрально-Черноземного района между количеством сделок, стоимостью земли и средними размерами проданных участков прослеживалась определенная взаимосвязь. Так, в восточных губерниях района цены на землю были ниже, количество сделок по куплепродаже земли меньше, а средние размеры проданных участков - больше. Курская губерния отличалась наибольшем количеством сделок в районе и самой дорогой по стоимости землей в районе. Среднее количество земли, приходящейся на одну сделку, в Тамбовской и Воронежской губерниях было практически одинаково, в Орловской губернии соответствовало Рязанской. Земельный рынок Тульской губернии занимал среднее место по рассмотренным показателям, и только стоимость земли в губернии была немного выше среднего. Разница в стоимости земли в губерниях Центрально-Черноземного района была менее значительна, чем в губерниях Центрально-Промышленного района.

Губернии Центрально-Промышленного района по приведенным показателям существенно различались. Например, в Московской, Владимирской и Костромской губерниях цены различались более чем в три раза. В Ярославской и граничащей с ней Костромской губерниях стоимость земли различалась в два раза, а средние размеры проданных участков - в три раза.

Таким образом, в течение рассматриваемого тридцатилетнего периода с 1863 по 1892 гг. в губерниях Центрально-Черноземного района тенденции на земельных рынках были более однородны, чем в губерниях Центрально-Промышленного района.

\section{Список литературы}

1. Анфимов. А.М. 1969. Крупное помещичье хозяйство европейской России (конец XIX - начало XX в.). АН СССР. Ин-т истории СССР. Москва, Наука, 394.

2. Военно-статистический сборник. Вып. IV. Под ред. генерал-майора Н.Н. Обручева. Санкт-Петербург, 1871.

3. Воронежские губернские ведомости № 1. Часть официальная. 1863.

4. Государственный архив Курской области (ГАКО). Ф. 4. Оп. 1. Д. 85, 89, 92, 96.

5. Дружинин Н.М. Русская деревня на переломе 1861-1880. 1978. Москва, Наука, 136.

6. Ковальченко И.Д., Милов Л.В. 1974. Всероссийский аграрный рынок, XVIII - начало XX в. Опыт количественного анализа. Москва, Наука, 399.

7. Корелин А.П. 1879. Дворянство в пореформенной России 1861-1904 гг. Москва, Наука, 304.

8. Литвак Б.Г. 1991. Русская деревня в реформе 1861 г. Черноземный центр. 1861-1895 гг. Москва, Издательство политической литературы, 93.

9. Литуев В.Н. 1997. Земельная собственность как дворянская монополия в капиталистической России. Москва, Калита, 148.

10. Лященко П.И. 1901. Очерки аграрной эволюции. Санкт-Петербург, б. м., 446.

11. Материалы по статистике движения землевладения в России. Вып. IV: Свод данных о купле-продаже земель в 45 губерниях Европейской России за тридцатилетие с 1863 по 1892 гг. Под ред. А.Е. Рейнбота. Санкт-Петербург, Тип. Киршбаума, 1901.

12. Материалы по статистике движения землевладения в России. Вып. ХIII.: Погубернские итоги мобилизации земель и средние земельные цены за 40-летие. 1863-1902 гг. Под ред. А.Е. Рейнбота. Санкт-Петербург, Тип. Киршбаума, 1907.

13. Материалы редакционных комиссий по крестьянскому делу. Санкт-Петербург, 1860.

14. Островский А.В. 2013. Зерновое производство Европейской России в конце XIX начале XX в. Санкт-Петербург, 418.

15. Проскурякова Н.А. 1973. Размещение и структура дворянского землевладения Европейской России в конце ХІХ - начале ХХ вв. История СССР. 1: 55-75. 
16. Святловский В.В. 1911. Мобилизация земельной собственности в России (1861-1908 гг.). Санкт-Петербург, Книгоиздательство «Начало», 116.

17. Статистика поземельной собственности и населенных мест Европейской России. Вып. І. Санкт-Петербург, 1880.

18. Статистика землевладения. Воронежская губерния. Вып. V. Санкт-Петербург, ЦСК МВД, 1905.

19. Статистика землевладения. Курская губерния. Вып. XXXVII. Санкт-Петербург, ЦСК МВД, 1906.

20. Статистический временник Российской империи. Серия III. Вып. 10. Санкт-Петербург, ЦСК МВД, 1886.

21. Цифровые данные о поземельной собственности в Европейской России. СанктПетербург, 1897.

\section{References}

1. Anfimov A.M. 1969. Krupnoe pomeshhich'e hozjajstvo evropejskoj Rossii (konec XIX nachalo XX v.) [Large-scale estates of European Russia (the late 19th century - early $20^{\text {th }}$ )]. AN SSSR. In-t istorii SSSR. Moscow, Nauka, 394 (in Russian).

2. Voenno-statisticheskij sbornik. Vyp. IV [Military Statistics, ed. 4]. Pod red. general-majora N.N. Obrucheva. St. Petersburg, 1871 (in Russian).

3. Voronezhskie gubernskie vedomosti № 1. Chast' oficial'naja. 1863 [Voronezh provincial statements N 1. Official part. 1863] (in Russian).

4. Gosudarstvennyj arhiv Kurskoj oblasti (GAKO) [State Archives of the Kursk Region (SAKR)]. F. 4. Op. 1. D. 85, 89, 92, 96.

5. Druzhinin N.M. Russkaja derevnja na perelome 1861-1880. 1978 [Russian village at the crossroads]. Moscow, Nauka. 136 (in Russian).

6. Koval'chenko I.D., Milov L.V. 1974. Vserossijskij agrarnyj rynok, XVIII - nachalo XX v. Opyt kolichestvennogo analiza [All-Russian agrarian market, 18 - early 20th century. Quantitative analysis attempt]. Moscow, Nauka, 399 (in Russian).

7. Korelin A.P. 1879. Dvorjanstvo v poreformennoj Rossii 1861-1904 gg. [Landed gentry in post-reform Russia (1861-1904)]. Moscow, Nauka, 304 (in Russian).

8. Litvak B.G. 1991. Russkaja derevnja v reforme 1861 g. Chernozemnyj centr. 1861-1895 gg. [Russian village after the reform of 1861 Central Chernozem region]. Moscow, Izdatel'stvo politicheskoj literatury, 93 (in Russian).

9. Lituev V.N. 1997. Zemel'naja sobstvennost' kak dvorjanskaja monopolija v kapitalisticheskoj Rossii [Monopolized land ownership by the nobility in capitalist Russia]. Moscow, Kalita, 148 (in Russian).

10. Ljashhenko P.I. 1901. Ocherki agrarnoj jevoljucii [Essays on the agrarian revolution ] St. Petersburg, b. m., 446 (in Russian).

11. Materialy po statistike dvizhenija zemlevladenija v Rossii. Vyp. IV: Svod dannyh o kupleprodazhe zemel' v 45 gubernijah Evropejskoj Rossii za tridcatiletie s 1863 po 1892 gg. [Statistics on Russian agricultural progress, ed. 4. Set of data related to the land mobility in 45 provinces of European Russia during the period from 1863 to 1892]. Pod red. A.E. Rejnbota. St. Petersburg, Tip. Kirshbauma, 1901 (in Russian).

12. Materialy po statistike dvizhenija zemlevladenija v Rossii. Vyp. XIII.: Pogubernskie itogi mobilizacii zemel' i srednie zemel'nye ceny za 40-letie. 1863-1902 gg. [Statistics on Russian agricultural progress, ed. 13. Results of land mobility in each province and average land prices during the period from 1863 to 1902]. Pod red. A.E. Rejnbota. St. Petersburg, Tip. Kirshbauma, 1907 (in Russian).

13. Materialy redakcionnyh komissij po krest'janskomu delu [Materials of the editorial commissions on peasant affairs]. St. Petersburg, 1860. T. 1. 1027 (in Russian).

14. Ostrovskij A.V. 2013. Zernovoe proizvodstvo Evropejskoj Rossii v konce XIX - nachale XX v. [A.V. Ostrovsky, 2013. Crop production of the European Russia in the late 19th century - early 20th century]. St. Petersburg, 418 (in Russian).

15. Proskurjakova N.A. 1973. Razmeshhenie i struktura dvorjanskogo zemlevladenija Evropejskoj Rossii v konce XIX - nachale XX vv. [Placement and formation of noble land ownership in European the late 19th century - early 20th]. Istorija SSSR. 1: 55-75 (in Russian). 
16. Svjatlovskij V.V. 1911. Mobilizacija zemel'noj sobstvennosti v Rossii (1861-1908 gg.). [Land mobility in Russia (1861-1908)]. SPb., Knigoizdatel'stvo «Nachalo», 116 (in Russian).

17. Statistika pozemel'noj sobstvennosti i naselennyh mest Evropejskoj Rossii. Vyp. I [Statistics of land ownership and localities of European Russia. Ed. 1]. St. Petersburg, 1880 (in Russian).

18. Statistika zemlevladenija. Voronezhskaja gubernija [Land ownership statistics. Voronezh Region]. Vyp. V. St. Petersburg, CSK MVD, 1905 (in Russian).

19. Statistika zemlevladenija. Kurskaja gubernija [Land ownership statistics. Kursk Region]. Vyp. XXXVII. St. Petersburg, CSK MVD, 1906 (in Russian).

20. Statisticheskij vremennik Rossijskoj imperii. Seriya III. Vyp. 10 [Annals of Statistika's of russian empire]. St. Petersburg, CSK MVD, 1886 (in Russian).

21. Cifrovye dannye o pozemel'noj sobstvennosti $\mathrm{v}$ Evropejskoj Rossii [Figures for the land ownership in European Russia]. St. Petersburg, 1897 (in Russian).

\section{ИНФОРМАЦИЯ ОБ АВТОРЕ}

Громова Виктория Валентиновна, аспирант кафедры российской истории и документоведения Белгородского государственного национального исследовательского университета, г. Белгород, Россия

\section{INFORMATION ABOUT ATHOR}

Viktoriya V. Gromova, postgraduate student of the Department of Russian history and prestudy Belgorod State National Research University, Belgorod, Russia 